\title{
Reciprocity in global social protection: providing care for migrants' children
}

Citation for published version (APA):

Dankyi, E., Mazzucato, V., \& Manuh, T. (2017). Reciprocity in global social protection: providing care for migrants' children. Oxford Development Studies, 45(1), 80-95.

https://doi.org/10.1080/13600818.2015.1124078

Document status and date:

Published: 01/01/2017

DOI:

10.1080/13600818.2015.1124078

Document Version:

Publisher's PDF, also known as Version of record

Document license:

Taverne

Please check the document version of this publication:

- A submitted manuscript is the version of the article upon submission and before peer-review. There can be important differences between the submitted version and the official published version of record.

People interested in the research are advised to contact the author for the final version of the publication, or visit the DOI to the publisher's website.

- The final author version and the galley proof are versions of the publication after peer review.

- The final published version features the final layout of the paper including the volume, issue and page numbers.

Link to publication

\footnotetext{
General rights rights.

- You may freely distribute the URL identifying the publication in the public portal. please follow below link for the End User Agreement:

www.umlib.nl/taverne-license

Take down policy

If you believe that this document breaches copyright please contact us at:

repository@maastrichtuniversity.nl

providing details and we will investigate your claim.
}

Copyright and moral rights for the publications made accessible in the public portal are retained by the authors and/or other copyright owners and it is a condition of accessing publications that users recognise and abide by the legal requirements associated with these

- Users may download and print one copy of any publication from the public portal for the purpose of private study or research.

- You may not further distribute the material or use it for any profit-making activity or commercial gain

If the publication is distributed under the terms of Article $25 \mathrm{fa}$ of the Dutch Copyright Act, indicated by the "Taverne" license above, 


\section{Reciprocity in global social protection: providing care for migrants' children}

\section{Ernestina Dankyi, Valentina Mazzucato \& Takyiwaa Manuh}

To cite this article: Ernestina Dankyi, Valentina Mazzucato \& Takyiwaa Manuh (2017) Reciprocity in global social protection: providing care for migrants' children, Oxford Development Studies, 45:1, 80-95, DOI: 10.1080/13600818.2015.1124078

To link to this article: https://doi.org/10.1080/13600818.2015.1124078

曲 Published online: 24 Dec 2015.

Submit your article to this journal

Џll Article views: 758

Q View related articles $\sqsubset$

View Crossmark data ¿

Citing articles: 15 View citing articles 5 


\title{
Reciprocity in global social protection: providing care for migrants' children
}

\author{
Ernestina Dankyi ${ }^{a}$, Valentina Mazzucato ${ }^{\mathrm{b}}$ and Takyiwaa Manuhc \\ ${ }^{a}$ Centre for Social Policy Studies, University of Ghana, Legon, Ghana; bDepartment of Technology and Society Studies, \\ Maastricht University, Maastricht, The Netherlands; ' Social Development Policy Division, Economic Commission for \\ Africa, Addis Ababa, Ethiopia
}

\begin{abstract}
Migration research tends to conceptualize migrants as providers of social protection for people back home. Yet the care conducted within transnational families and the way it is organized is an integral part of a global social protection system which is based on reciprocity between migrants and their families in their home countries. This system relies on the work of people back home just as much as on the remittances of migrants overseas. Drawing on ethnographic data from 34 caregivers, we provide a detailed description of the work conducted by people in Ghana to care for migrants' children and analyze what caregivers do to make this work possible. We find that caregivers have small networks of support they can rely on and identify the strategies they develop when remittances are not forthcoming or enough to cater for the material needs of migrants' children.
\end{abstract}

\section{ARTICLE HISTORY}

Received 5 June 2015

Accepted 23 September 2015

\section{KEYWORDS}

Transnational care; migration; caregivers; global social protection; reciprocal relations; Ghana

\section{Introduction}

While the care work involved in transnational families has received recent academic attention, it is mainly within the field of "family studies" (e.g. Baldassar \& Merla, 2014). Yet care that is conducted between members of transnational families and the way it is organized is an integral part of a system of global social protection which migrants and their families devise, especially in situations where they do not have access to more formalized systems of social protection. Some authors have highlighted the "informal" means of social protection amongst migrants (Kabki, Mazzucato, \& Appiah, 2004; SabatesWheeler \& Waite, 2003), focusing primarily on help in the form of remittances which migrants provide to their social networks "back home". What is missing from academic scrutiny is the care work that people "back home" provide for migrants, especially when migrants from the global South move to the global North and are not eligible to benefit from formal social protection systems. This paper offers a detailed description and analysis of the work conducted by people in Ghana in caring for children whose parents have migrated to Europe. Childcare is a form of social protection which is needed to allow migrant parents to work, yet formal day-care in migrant-receiving countries tends to be costly, and if migrants are undocumented they refrain from using formal day-care institutions for fear of being identified. Furthermore, even if parents could solve the issue of using day-care in the receiving 
country, often they are not able to migrate with their children due to the strict migration regulations in the global North, restricting families from migrating together. For all these reasons, parents in the global South may opt to leave their children at home with a caregiver while they migrate in search of income-earning possibilities to better the future prospects of their children and other family members.

This form of transnational care is discussed but not often analyzed in the transnational migration literature, that is, the "work" that is done "back home" to enable migrants to migrate - as research tends to conceptualize the migrant as the provider of social protection for people back home. It is mainly feminist literature on the global care chain which has identified a care drain in the global South as women move away from their children to care for the children of women in the North. However in this literature, little focus is given to the actual caregiving work which takes place in the global South by caregivers (Ehrenreich \& Hochschild, 2002; Hondagneu-Sotelo \& Avila, 1997; Parreñas, 2001).

This paper engages with the literature on transnational families by focusing on the kin-work conducted in the global South to provide social protection, in the form of childcare, to transnational families. We focus on the care work performed for migrants' children by caregivers in the country of origin. We know from reports (UNICEF, 2006) and recent academic work (Graham \& Jordan, 2011; Mazzucato et al., 2015; Nobles, 2011; Parreñas, 2001; Vanore, Mazzucato, \& Siegel, 2015; Wu, Lu, \& Kang, 2015) that from the perspective of origin countries, children who have at least one parent abroad constitute a significant phenomenon in diverse countries such as China, Moldova, Georgia, The Philippines, Sri Lanka, Mexico and Ghana. We argue that the work conducted in these countries to care for these children constitutes an important source of global social protection which needs to be recognized and understood when thinking about how social protection programmes can be devised to cater to mobile populations.

\section{Transnational care}

A large number of studies on transnational families has shown how migrants care for those they leave behind mainly via remittances, long-distance communication and, to a lesser extent, through return visits (Coe, 2011; Dreby, 2010; Hondagneu-Sotelo \& Avila, 1997; Parreñas, 2005; Schmalzbauer, 2004; Wong, 2006). Scholars who study transnational parenting activities emphasise migrant parents' creative efforts to keep family members connected to and involved with one anothers' lives, even in the case of prolonged separation, often through the use of information and communication technologies (Fresnoza-Flot, 2009; Madiannou \& Miller, 2012). Through what some studies have termed "transnational care practices" (Graham \& Jordan, 2011), "rituals of transnational households" (Horst, 2006), "global householding" (Douglass, 2006) and a "tool kit of transnational family relations" (Banfi \& Boccagni, 2011), migrant parents are able to keep close ties with the children they leave behind. Parents are able to provide for the material needs of their children through remittances, while the communications environment engendered by new information technologies helps them offer emotional and social support to their children and the children's caregivers from a distance. They also remain involved in the decision-making process with regards to their children's upbringing through frequent contact with their children and the caregivers (Poeze \& Mazzucato, 2012).

At the same time, a transnational approach highlights the reciprocal processes which are implied in organizing care across borders, or what Baldassar and Merla (2014) term "care circulation". With respect to caring for children, migrant parents arrange care from the host country in order to ensure their children's welfare. In doing so, they also provide for a caregiver's needs in the form of financial remittances, housing or inputs to a business (Mazzucato, 2011; Van der Geest, Mul, \& Vermeulen, 2004). The bulk of academic attention has focused on these flows from the migrant to a child and caregiver. Yet such flows are accompanied by reciprocal flows of resources and services provided by caregivers in the home country with whom migrants leave their children, or what Mazzucato (2011) termed "reverse remittances". When parents migrate, children are left in the care of grandparents, aunts, fathers, and non-kin such as teachers, friends and preachers (Åkesson, Carling, \& Drotbohm, 2012; Bernard, Landolt, \& Goldring, 2005; Dankyi, 2011; Dreby, 2010; Parreñas, 2005). Schmalzbauer (2004) 
describes caregiving in this context as a cross-border division of labour in which production occurs in the migrant's host country and reproduction in the home country. Furthermore, she argues that caregivers play an important role in shaping how children feel about having migrant parents. When a grandmother explains to a child that her mother left in order to provide for the child's needs, this helps the child to feel loved and cared for by her mother. Yet, with some notable exceptions (Dreby, 2010; Fresnoza-Flot, 2014; Moran-Taylor, 2008), the overwhelming academic focus has been on the migrant side of transnational care, which means we have scant knowledge as to how care for migrants' children is carried out and what implications this has for the lives of the caregivers.

Transnational social caring, which best describes the actual work of caring for migrants' children, is embedded within local normative contexts (Fog Olwig, 2014; Mazzucato \& Schans, 2011). In many African countries, norms of social parenthood and child fostering, where people other than the biological parents take on responsibility for the care of children (Clark, 1999; Fayorsey, 1993), are important to consider when understanding why and how caregivers engage in the provision of care. Social parenthood and child fostering are widely practiced and acceptable phenomena in Ghana (Bledsoe \& Sow, 2011; Goody, 1982; Nukunya, 2003; Oppong, 1982). While norms of social parenthood and child fostering have developed largely within national contexts, they facilitate finding care solutions when parents migrate: caregivers may take on their roles with ease or even when they do not want to they nonetheless feel compelled to given such norms (Dankyi, 2014). At times migrants leave home without making explicit arrangements as they assume a carer will be found within the extended family (Dankyi, 2014), and children do not necessarily suffer from the migration of their biological parents or feel they are at a disadvantage compared to children living with both biological parents (Mazzucato et al., 2014). State intervention in the welfare of children is often limited to those who are deemed particularly vulnerable, such as orphans and abandoned children. Yet, the first point of contact for orphaned and vulnerable children has always been the extended family; it is under rare circumstances that these children are sent to institutional care.

These local normative contexts have been well documented in the anthropological literature, yet little work exists on how they relate to the transnational context (Fog Olwig, 2014; Øien, 2006). Furthermore, while much is known about how migrants conduct parenting at a distance, not much exists by way of exploration of the transnational work involved from the perspective of the caregiver. In this paper we look at the work which caregivers engage in, in order to make transnational care arrangements function, and how this serves as an important form of social protection for migrants. Often, migrants from developing countries are hardly considered in need of social protection from the perspective of the migrant origin countries; they are locally regarded as lucky and wealthy. However, migration may entail a wide range of vulnerabilities and risks (Sabates-Wheeler \& Waite, 2003). While the need to manage risk and secure livelihoods can be the main driver of migration decisions, a derived demand for various forms of social protection, state and non-state, may also arise from the migration process (Sabates-Wheeler \& Waite, 2003). The precarious situation faced by some migrants has implications for the immediate family, especially spouses and children left behind, further increasing their levels of vulnerability which the migrant sought to alleviate in the first place by migrating. There is a strong need to implement social protection policies to protect migrants against the adverse economic and social consequences of their vulnerability (Sabates-Wheeler \& Waite, 2003). Yet, we will argue in this paper that there is also a need to provide social protection transnationally, so that social protection policies for migrants are accompanied by policies in migrants' home countries addressing the vulnerabilities of those replacing the migrant at home to conduct care work.

\subsection{Social protection in the local context}

While formal social protection systems exist in many countries, for most developing countries such as Ghana, citizens rely predominantly on informal systems. An overview of existing formal social protection programmes in Ghana places them in three categories, following Devereux and SabatesWheeler's (2004) transformative social protection framework: (1) social assistance to extremely poor 
individuals and households; (2) social welfare services to those who need special care and support; and (3) social insurance to protect people against the risks and consequences of livelihood, life-cycle and other shocks. Current social protection programmes in Ghana are the Livelihood Empowerment against Poverty, the National Health Insurance Scheme, and the Ghana Social Opportunities Project. An impact analysis of the existing programmes reveal that while a number of vulnerabilities have been identified and programmes developed to address them, formal social protection in Ghana suffers from poor targeting and relatively low coverage, and to date, the interventions have focused on social assistance, rather than social welfare and social insurance (UNICEF, 2009).

In addition to these formal social interventions are various forms of informal systems. Concepts of social solidarity, based on the notion of kin-based mutual support, are solidly anchored in traditional Ghanaian culture, and to some degree these informal mechanisms still exist today. Bortei-Doku Aryeety and Doh (2007) identify five main sources of informal social protection, which are all based on principles of reciprocity and mutual exchange: kin-based support systems, remittances, trade associations, faith-based support networks, and credit societies. These forms of reciprocity function as a safety-net and opportunity structure for families and individuals in the context of the limited formal/ state mechanisms which exist to mitigate risks. These safety nets are particularly crucial for the majority of Ghanaians who operate in the informal sector and who are not adequately covered by the limited formal social systems (Bigombe \& Khadiagala, 2003; Nukunya, 2003).

Economic hardship experienced by Ghanaians in the past decades of large economic cut-backs, high inflation rates and a general increase in the cost of living has made support from kin and other social groups more difficult to come by (Bigombe \& Khadiagala, 2003; Nukunya, 2003). Middle-class Ghanaians can barely manage to stretch their resources beyond their own nuclear families. The dire economic situation is worse in urban areas where paying for basic utilities, educating one's children, and fulfilling other pressing obligations makes life difficult, especially for many low-income earners. Within the period of this study (2011-2013), Ghana experienced the removal of fuel subsidies, which resulted in increased fuel prices leading to widespread increases in the prices of goods, especially consumer goods. This was accompanied by very large increases in transportation fares and in the price of Liquefied Petroleum Gas for domestic purposes. These unfavourable economic conditions within a system of inadequate formal social protection mechanisms, coupled with crumbling informal support, have left many Ghanaians, including caregivers of migrant children, vulnerable to risks and other shocks.

\section{Data and methods}

The paper is based on an ethnographic study which followed the lives of 15 caregivers in a matched sample of migrant parents in the Netherlands and children and their caregivers in Ghana for over two years. The study is supplemented with one-off semi-structured interviews with a non-matched sample of 19 other caregivers in the Greater Accra and Ashanti Regions. These locations are known for their high rates of migration to North America and various destinations in Western Europe (Mazzucato, van den Boom, \& Nsowah-Nuamah, 2008). The ethnographic research with 15 matched-sample caregivers involved the use of the Simultaneous Matched Sample methodology (Mazzucato, 2009), which entailed multiple researchers located in The Netherlands and Ghana sharing information on a regular basis in order to gain an understanding of how transnational child care arrangements function (Poeze \& Dankyi, 2013).

The selection of cases started in Amsterdam where approximately 60\% of Ghanaians in The Netherlands live. Different entryways were used to gain access to a diversity of Ghanaian migrant parents with children living in Ghana. We recruited 15 parents from churches, from previous contacts of one of the authors, from markets, and via acquaintances. Each parent was asked and gave consent for us to contact the caregivers of their children in Ghana. In addition, in Ghana, 19 other caregivers were selected based on a school survey conducted by another project which was part of the overall research programme of which this research was also a part. These 19 caregivers had children 
of migrants based in the global North (one in The Netherlands, and the rest in USA, Canada, UK, Germany and Italy), and were not matched to migrants in the host country. These additional caregivers were included to ensure that we did not only have "problem-free" cases, as might be the case when using matched cases because of the double consent which is needed from respondents on both sites. Later, this proved not to be an issue.

For the ethnographic studies with the 15 caregivers in the matched sample, the main data collection tools were in-depth interviews, observations during visits and participation in some of their social activities during a two-year fieldwork period between 2010 and 2013. During the research period, we kept in regular contact with respondents via phone calls between visits and through informal visits during which we did not conduct interviews but used the opportunity to observe and learn about the care arrangement. Questions focused on understanding the way transnational child-raising arrangements function, which included practical ways in which care is arranged, decision-making in the care arrangement, how the care arrangement came about, and the history of the arrangement. Additionally, we looked at the responsibilities of the caregiver towards the children and the migrants, the compensation and expectations they had of the care arrangement, as well as the emotions such an arrangement evoked. Where semi-structured interviews were recorded, these were fully transcribed. The transcribed interviews and notes that were taken during in-depth interviews, our observations, and our exchanges with our colleague in The Netherlands who studied the migrants were analyzed by identifying recurring themes and concepts and the factors which seemed to be associated with them. This was done manually.

Of the 34 caregivers in total, 30 were related by kinship to the children in their care, with grandmothers constituting a majority. The remaining four non-kin caregivers comprised two teachers, a friend of the migrants, and a hired live-in caregiver. Twenty-one caregivers were economically active and did not depend on the remittances from the migrants for their personal upkeep. The remaining caregivers, consisting mainly of grandmothers, were either not fit to work or had stopped active economic activity in order to have time to raise the children of migrants in their care. These caregivers thus depended on the remittances of the migrants for both their own and the children's upkeep. Of these, six caregivers had other sources of income such as remittances from their own adult children or support from a spouse. Twenty-one caregivers were married and 17 of them lived with their husbands in the same house as the migrants' children, while the remaining lived apart from their husbands. There were 18 caregivers who had children of their own in the same house as the migrants' children.

\section{The work of caregivers in transnational care arrangements}

We begin this section with three vignettes of different caregivers' experiences. Each vignette describes how the caregivers entered into their care arrangements, the care they provide for the children, and the accompanying challenges.

\section{Cecilia ${ }^{1}$ - caring against her will}

Cecilia was 61 years old when we first met her in 2011. She had been entrusted with the care of five children of her maternal niece (Joyce) who lived in the Netherlands. Cecilia lived in a family compound house with her aged mother, her youngest child who was 17 years old at the time, and other members of her extended family. She shared her two-room apartment with her son and her niece's five children. During our first interview, Cecilia intimated that her niece had created a huge inconvenience for her by virtually imposing the children on her. According to Cecilia, the original arrangement with Joyce was for her to take care of Joyce's youngest child who was barely six months old at the time Joyce was leaving for the Netherlands. The four older children had been left in the care of their father. Shortly after Joyce left for the Netherlands, however, she asked Cecilia to accept the four older children following a big argument she had had with her husband. Cecilia said she refused to take the children in because she did not have enough room to accommodate them. Moreover, she informed Joyce that she did not have time to raise the children, especially as there were two toddlers whose care would require a lot of her time. Cecilia was running a stationery shop out of her house at the time, which created time and space constraints. The only reason she agreed to have them was her niece's insistence and firm promise that the four children would live with her for a maximum of six months, within which time the process of reuniting with her 
children which she had started while in The Netherlands would be completed. However, the children stayed with Cecilia throughout the two-year period we engaged with her. During our last interview in 2013, Cecilia said: "It has been more than two years now. I love the children but I have really regretted accepting to take them in. If I knew it would take this long, I would not have entangled myself in this". (Accra, November 2011)

\section{Kessewaa - a difficult situation}

In 2000, following several complaints from her sister that her son's ailment was draining her financially and physically, Kesewaa suggested to her sister who was living in the United States that she should send her sick 14 year-old-son to Ghana so she could find an alternative cure for the boy's ailment. Her sister agreed and her nephew has been with Kesewaa ever since. Her sister's other three children (19, 11 and 5 years old) followed in 2002 after their mother's divorce from the children's father. According to Kessewaa, they were quite easy to handle. She nevertheless recounted the challenges she faced with the care arrangement in this way:

The difficult part of my role as caregiver was my second nephew's ailment. My husband and I went through hell trying to get him cured. We spent most of the early days after he was sent to us moving from one hospital to the other, but to no avail. I was then running a grocery shop at the market and the time spent in the hospitals meant that I paid less attention to the shop. Somebody advised me to send him to a prayer camp in Accra. I discussed this with my sister and she agreed. We (the boy and I) spent an entire year there. (Kumasi, July 2012)

During the year she spent at the prayer camp, Kesewaa was almost cut off from friends and family and could not take part in any of her usual social activities because the camp maintained strict rules which required spending a lot of time in seclusion to concentrate on the spiritual exercise. She also said: "By the time we returned from the camp the shop was closed. All the items were gone and the girl was nowhere to be found. I had lost my entire capital and the shop too since I could not continue to pay for the rent. Fortunately, the spiritual exercise yielded results because the boy has since been well. But every once in a while he falls ill and has to be rushed to the hospital". (Kumasi, July 2012)

\section{Awurakua - things are "fine, fine"}

Awurakua is raising her sister's daughter together with her own son and her three step-children. She recounts:

My sister was living with her husband in a suburb of Accra. She had already had twin girls who were about three years old and was pregnant with Amma. She invited me to move in with her and assist with care of the twins when her husband travelled abroad. I had a son who was 2 years at the time. I left my son with my mother and moved in with my sister. I was with her when Amma was born and I started minding her right from infancy. My sister later joined her husband in the Netherlands. She sent the twins to their paternal grandmother and Amma was 'automatically' left in my care at the age of two. At the initial stages of taking care of Amma after my sister left, I was solely in charge of her upkeep. I understood from my sister that things were a bit tough for them. Once in a while they would send me some money. My trading business was doing well so I could afford to take care of both Amma and my son whom I had brought to join us. I could not check on her schoolwork because I can hardly read or write but one of my brothers had been doing that for me. He is the one that attends PTA meetings and also any activities related to school. My sister and her husband started remitting regularly for Amma's upkeep when she was about 8 years old. One day my sister's husband called me and started asking about my son's education and then promised to pay his fees. I was pleasantly surprised. They have been paying the fees for my son till today. They usually send us money at the beginning of each school term. When they send the fees, they usually add some extra amount to support our food costs. I do not make demands for money to take care of Amma because I know it is not easy for them. I appreciate the fact that they have been paying for my son's fees for some time now. It helps a lot even though I have made other provision for him. (Accra, May 2012)

While in all three cases kinship, notions of social parenthood, and reciprocity, underlie the transnational child raising arrangements, the vignettes show different pathways that the three caregivers followed in their care arrangements as well as how differently they can work: in some cases arrangements seem fraught with tension, while in others they seem to work easily. Kessewaa and Awurakua agreed to care for the migrants' children without hesitation, while Cecilia raised genuine concerns about her ability to take the children into her care, but later had to accept the situation, owing to her niece's insistence and firm promise that the care arrangement was temporary. The vignettes also show differences in the challenges associated with providing care for the children. Both Cecilia and Kesewaa had to give up their former employment and incurred a loss of income, given the extreme circumstances of their arrangement (caring for many children and for one very ill child, respectively). Awurakua, on the other hand, had a relatively easy situation with remittances forthcoming on a regular basis, some extra funds for her own family, and people in her local network who could provide a type of care she 
was unable to give; that is, helping the child with her schoolwork through the assistance of a brother. We will refer to portions of the vignettes in the subsequent sections of the paper.

\subsection{Care work in transnational families}

We draw on network (Finch \& Mason, 1993; House, 1981; Israel, 1982) and transnational care studies (Baldassar, Baldock, \& Wilding, 2007; Baldassar \& Merla, 2014) in order to conceptualize the care provided by caregivers under three main constructs: emotional (psychological wellbeing), material care ("hands on" and financial), and social care (advice, suggestions aimed at socializing the children into responsible adulthood). The provision of care can be virtual, taking place across borders (Baldassar et al., 2007), such as those provided by the migrant parents, or proximate as provided by the caregivers. Providing care for younger children can be very time consuming as it demands the full attention of the caregivers. Younger children require what Goody (1982) describes as "nurturant care", and they are entirely dependent on the caregiver for all their needs.

The caregivers of younger children, such as Cecilia and Maa Asafo (a grandmother who was taking care her three migrant daughters' eight children) described daily schedules which are characterized by care practices such as cooking, feeding and bathing. For instance, Maa Asafo, who takes care of eight grandchildren including three toddlers, indicated that her day usually begins at 4:30 am and is filled with different care activities until she retires to bed. The caregivers also take care of the children when they are sick and make sure they behave in a socially approved manner. Additionally, caregivers have to ensure that children go to school and receive help with their schoolwork. Caregivers who are unable to assist with schoolwork may arrange for someone in their network of family and friends to perform this service or, in consultation with the migrant, arrange for extra tutoring at home.

Provision of care is less time consuming for caregivers who have older children in their care as they are more able to take care of their own daily needs. Some of these children can cook and provide some small services such as running errands and washing dishes for the caregivers. Kesewaa mentioned that she does less for the children now that they are old enough to attend to their own personal needs. At this stage of the children's lives, what the caregivers are mostly concerned about is supervising and guiding them to make good choices and to concentrate on their studies or apprenticeships.

Although taking care of older children may seem less time consuming, various caregivers of older children experienced stressful periods, especially when the children have to move from Junior High School to Senior High School (SHS), or when there are disciplinary issues. School transitions can be quite hectic for caregivers. During the fieldwork period, Cecilia had to secure admissions into SHS for two of the children in her care. During one of our visits, she mentioned she had spent almost every day of that week in this pursuit and was elated to have finally found schools to admit both of them. An additional challenge that some caregivers, especially ageing grandmothers, have when children get to this stage is the issue of discipline. As grandmothers got older, it became difficult to "control" the growing children in their care. Maa Asafo said:

The first time he stayed out late, I really spanked him and he stopped for a while. Now he has started again. He is growing taller and bigger, and I do not think spanking him will do any more. In fact I do not have the strength to hit him. (Kumasi, May 2012)

Sometimes older children are sent to boarding schools and therefore child-raising is shared between the schools and the caregivers when the children spend the school holidays at home. The carers are therefore less burdened with household chores and have to worry less over disciplining the children. For children attending boarding school caregivers have the responsibility of to visiting them in school, which is usually allowed once a month, and also attending periodic meetings such as Parent Teacher Associations to check on the children's progress. Like Awurakua, some caregivers have members in their networks who assist by attending these school meetings.

An area of care which can be extremely time consuming, not to mention financially taxing, is when children fall seriously ill, as happened to Kesewaa with her sister's son. This was not a singular 
Table 1. Caregiver's care network: size and composition.

\begin{tabular}{|c|c|c|c|c|c|c|}
\hline \multirow[b]{2}{*}{ Caregiver } & \multirow[b]{2}{*}{ Location } & \multirow[b]{2}{*}{ Size } & \multicolumn{2}{|c|}{ Sex of Network Member } & \multicolumn{2}{|c|}{ Type of Relationship } \\
\hline & & & Male & Female & Kin & Non-Kin \\
\hline$\overline{N a k i}$ & Accra & 3 & 2 & 1 & 3 & \\
\hline Pomaa & Kumasi & 4 & 2 & 2 & 3 & 1 \\
\hline Kwesi & Accra & 1 & 1 & & 1 & \\
\hline Takyi & Kumasi & 4 & 2 & 2 & 4 & \\
\hline Akua & Kumasi & 1 & 1 & & 1 & \\
\hline Awurakua & Accra & 3 & 2 & 1 & 3 & \\
\hline Jennifer & Kumasi & 5 & 2 & 3 & 5 & \\
\hline Victor & Accra & 1 & & 1 & 1 & \\
\hline Cecilia & Accra & 3 & 1 & 2 & 3 & \\
\hline Georgina & Kumasi & 2 & 1 & 1 & 2 & \\
\hline Owonta & Kumasi & 4 & 1 & 3 & 3 & 1 \\
\hline Kissiwaa & Accra & 3 & 1 & 2 & 3 & \\
\hline Mama K & Kumasi & 4 & 3 & 1 & 4 & \\
\hline Christie & Kumasi & 3 & 1 & 2 & 1 & 2 \\
\hline Fosua & Kumsai & 6 & 2 & 5 & 4 & 2 \\
\hline
\end{tabular}

Source: Fieldwork with 15 matched cases, TCRA project, 2010-2013.

case. Ophelia, the only paid caregiver in our study, explained her experience when one of the three boys in her care fell seriously ill and was almost at the point of death. The oldest boy was admitted to the hospital three times in one month. She said: "The boy was almost gone, and I was so scared partly because I was losing the boy and was also thinking of how I would explain this to the parents" (Kumasi, August 2013). She left the other two children in the care of her friend and the migrant's younger brother. Describing the boy's illness as a spiritual attack, Ophelia confided that she had gone through a difficult time during the child's ailment. The experience took a big toll on her: she lost weight from the emotional agony of almost losing the child and from the continuous prayer and fasting her pastors had instructed her to do in order to avert the spiritual attack which she believed was causing the boy's ailment.

In general, providing care for migrants' children requires an alteration in a caregiver's daily life and especially in their participation in social functions. Participation in social functions is very important in Ghana, especially for the elderly, because apart from the company it provides it is a way of ensuring people will receive the needed support when in the future they are bereaved or in need of reciprocal assistance. Cecilia and Kessewaa shared similar experiences of a disruption in their regular routines and having to forego participation in social events in order to focus on their caregiving activities. Maa Asafo mentioned she had to cut down on attending social functions, especially funerals and women's fellowship meetings in her church. Sacrifices in one's private life can go much deeper than social functions. Kumiwaa, who was raising her sister's children, had to be separated from her husband, as there was not enough room in the house to accommodate both of them and the children. Kumiwaa got married a few years after she had assumed responsibility for her sister's children but she and her husband lived apart - Kumiwaa in Accra and her husband in Kumasi - because she had to take care of her migrant sister's children. This meant that she shuttled between Kumasi and Accra in order to spend time with her husband. At the time of the research, the children, who were 15, 17, 19 years old, were old enough to take care of themselves, so Kumiwaa could spend longer periods in Kumasi, much to the chagrin of the migrant parents who thought she was leaving the children by themselves for far too long.

\subsection{Receiving support: caregivers' networks of care}

Caregivers are not alone in providing care. Especially in societies such as Ghana where norms of social parenthood are common, other people, especially in the extended family, can be called upon to help with care. In this study, we describe the transnational network of caregivers using the characteristic 
Table 2. Caregivers support networks by type of support.

\begin{tabular}{|c|c|c|c|}
\hline Type of support & Network members & $\begin{array}{l}\text { Avg. number of people } \\
\text { who provide support }\end{array}$ & Comments \\
\hline $\begin{array}{l}\text { Financial (paying for educa- } \\
\text { tion, medical bills, food and } \\
\text { clothing, etc.) }\end{array}$ & $\begin{array}{l}\text { Migrant parents } \\
\text { Caregiver's siblings } \\
\text { Friend of migrant parent }\end{array}$ & 1 & $\begin{array}{l}\text { Siblings and friends are called upon } \\
\text { when caregiver is in dire straits }\end{array}$ \\
\hline $\begin{array}{l}\text { Proximate care (daily care } \\
\text { such as food, washing, etc.) }\end{array}$ & $\begin{array}{l}\text { Household helpers } \\
\text { Caregiver's adult children } \\
\text { Caregiver's mother } \\
\text { Caregiver's husband }\end{array}$ & 2 & $\begin{array}{l}\text { Live in same household as caregiver } \\
\text { and child }\end{array}$ \\
\hline $\begin{array}{l}\text { Who educates child to behave } \\
\text { (discipline and advice)? }\end{array}$ & $\begin{array}{l}\text { Migrant parents } \\
\text { Caregiver's husband } \\
\text { Caregiver's mother } \\
\text { Caregiver's brother } \\
\text { Caregiver's adult children }\end{array}$ & 2 & $\begin{array}{l}\text { With the exception of migrant parents, } \\
\text { all the others live in the same house- } \\
\text { hold as caregiver }\end{array}$ \\
\hline $\begin{array}{l}\text { Who checks on child's } \\
\text { progress in school or an } \\
\text { apprenticeship? }\end{array}$ & $\begin{array}{l}\text { Caregiver's brothers } \\
\text { Caregiver's adult child } \\
\text { Caregiver's husband } \\
\text { Some migrant parents }\end{array}$ & 2 & $\begin{array}{l}\text { With the exception of the caregiver's } \\
\text { husband, others do not live in the same } \\
\text { household as the caregiver and the } \\
\text { child. This type of support is usually } \\
\text { required on an intermittent basis }\end{array}$ \\
\hline $\begin{array}{l}\text { Who makes important deci- } \\
\text { sions (regarding education } \\
\text { and healthcare, especially } \\
\text { those with financial implica- } \\
\text { tions, or when to communi- } \\
\text { cate with migrants)? }\end{array}$ & Migrant parents & 2 & $\begin{array}{l}\text { Major decisions are made together } \\
\text { with the migrant parents. However, } \\
\text { communication with the parent is } \\
\text { always initiated, and thus decision is } \\
\text { made, by the migrant parent }\end{array}$ \\
\hline $\begin{array}{l}\text { Who do caregivers have argu- } \\
\text { ments with about the child's } \\
\text { upbringing? }\end{array}$ & Migrant parents & 1 & $\begin{array}{l}\text { Arguments are usually about dif- } \\
\text { ferences in how the child should be } \\
\text { treated and raised }\end{array}$ \\
\hline $\begin{array}{l}\text { Who do caregivers seek advice } \\
\text { from about the care of the } \\
\text { child? }\end{array}$ & $\begin{array}{l}\text { Migrant parents } \\
\text { Caregiver's adult children }\end{array}$ & 1 & $\begin{array}{l}\text { Caregivers usually seek advice when } \\
\text { the child or children became } \\
\text { rebellious or troublesome }\end{array}$ \\
\hline
\end{tabular}

Source: Fieldwork with 15 matched cases, TCRA project, 2010-2013.

features of networks which Social Network Analysis (SNA) highlights, namely their size, composition, spatial dispersion and function (i.e., the type of support they render) (Wetherell, 1998). We identified the ties in a network primarily through a name-generator questionnaire, another important methodological feature borrowed from quantitative SNA (Burt, 1984; Campbell \& Lee, 1991). We also asked hypothetical questions (for example, "when the child is ill, who can you ask to help with the daily care?") in order to get a sense of the kind of care support (emotional, material and social) caregivers received from specific members in their network, even when a particular situation had not yet occurred. We found that networks were comprised of both male and female kin and non-kin members who provided a broad range of support to caregivers. They played different roles depending primarily on their availability, access to resources and expertise in a particular area, for instance education. According to the caregivers, there are network members who can be mobilized because of their relationship to the caregiver; others, especially the migrant parents, who can be mobilized out of a sense of obligation to the children; and yet others who can be mobilized because of their past relationships with the migrants. Tables 1 and 2 provide some characteristics of the members in the caregivers' network and their support functions, respectively.

\subsubsection{Size of networks}

The most striking finding of our network study was how small caregivers' care support networks actually are. The average number of people that a caregiver could draw upon for help was three. Furthermore, this number becomes smaller when we consider the day-to-day care which occupies caregivers most. While uncles or aunts who can go to the occasional parent-teacher meeting at school were not too hard to come by, finding someone to stay at home to care for a sick child was more difficult. 
Observing the lives of caregivers revealed some of the challenges in finding help with caregiving tasks, especially in urban areas such as where we did our research. Distances in the cities are expanding with increasing populations while poor transport infrastructure is making movement within the city difficult, with long hours spent in traffic jams. This makes it costly to move across the city and to accommodate unplanned-for needs, such as caring for a sick child, even if the caregiver had the time free to do so. Work schedules of individuals tend to be long and the distance between home and work places exacerbates the issue. Kumiwaa exemplifies how the urban context impinges on the availability of assistance from others. She was bereaved and had to leave for a funeral in her hometown. The only family member who also lived in Accra on whom she could have relied to care for the child could not assist because of the distance between their home and hers. She therefore had temporarily to remove the oldest child in her care from boarding school in order to help care for the youngest child during her absence. Those caregivers who were best placed to render assistance were those who lived in the same compound as the caregiver and the migrant's child, or in the same neighbourhood. Yet these characteristics of support networks are rare in today's urban contexts.

Another factor which explains the small network is the economic hardships faced by many of the caregivers and the people in their networks. Some caregivers had low levels of education and worked mainly in petty commerce and low-paying jobs. They often had to work hard just to sustain their own immediate nuclear families. The economic situation is worse in the cities where this study was conducted because of the escalating costs of living. Paying for basic utilities, educating one's children, and fulfilling other social obligations, such as attending funerals, make life in the cities almost unbearable for lower-income earners. Meanwhile, one major challenge caregivers are constantly faced with is the inadequacy and irregular flow of remittances, which means that some caregivers needed financial assistance from members in their network.

Financial assistance for caregivers is hard to come by. Apart from the migrant parents in the network of caregivers and a few instances where caregivers can rely on a friend or a sibling to support them financially, most of the people in their networks perform non-financial functions and caregivers do not count on them for financial assistance. Cecilia intimated that because she lives in the same compound with most of the members in her network, she is aware that they have their own financial difficulties. Thus, she hardly approaches any of them for financial assistance. Kumiwaa also said she did not have anybody within her network to turn to when remittances were delayed. She explained: "Most of our relatives here in Accra are not in the position to help us" (Accra, May 2011) As a result, her sister's children in her care usually have to skip school for several days until their parents are able to send money for them to go to school.

\subsection{Financial resources}

Remittances from migrants are often described in the literature as some of the benefits which caregivers gain from taking care of migrants' children. Indeed, some of the caregivers we interviewed experienced such benefits and seemed to have a relatively easy time in paying for the children's expenses as well as their own. Awurakua, in the vignette, is a case in point. Similarly, Maame Ama, who was taking care of her brother's child, explained that she hardly has any financial difficulties. She commented that "nsesa ka daa", meaning there was always a surplus. Maa Victoria was of a similar opinion. In her case, the child's father always sends her a monthly allowance in addition to the money requested for the child's upkeep. Ophelia, the only hired caregiver we encountered, also maintained that she never had any financial challenges because the children's father sends money to pay for every single expense for the children and additionally, she receives a monthly salary. Some caregivers alluded to the fact that migrants send them money or gifts even without their asking, as in Awurakua's case. In general, the above-mentioned caregivers as well as others had independent sources of income, such as their own shops or commerce activities; so in the event that remittances were delayed, they were able to cover any incidental costs. Furthermore, they mentioned the migrants usually reimbursed them for the children's expenses so that their personal income was hardly affected. Thus, a combination of regular 
and sufficient remittances from migrants and a regular independent source of income of caregivers often resulted in less financial strain on the caregiver and fewer tensions with the migrant.

\subsubsection{Insufficient remittances/using their own resources}

The situation, however, could be quite different for caregivers with inadequate remittances, lack of financial assistance from members of their networks, and sometimes with no income-earning activities of their own. Such caregivers were found to devise different strategies in order to be able to provide adequate care. One such strategy is to use their own income to cover the basic costs of care, as illustrated by Cecilia. When we met her in 2011, Cecilia was receiving GH\$ 200 (75 Euros) every month to cover the daily expenses of the five children in her care. The amount, which was meant to last for a month, was barely enough for 10 days. We suggested she prepare a log sheet of her weekly expenditure, which revealed that she spent about GH\$132 per week on the children. In addition to this regular weekly expenditure, there were fixed monthly expenses such as haircuts and utility bills, especially electricity and water bills. Then there were the incidental expenditures, especially from the schools. From Cecilia's estimated expenditure on the children, it was apparent that the monthly remittance she received was grossly insufficient. To manage this, she used her own resources such as receipts from the stationery shop she operated. When she ran out of stock, she started spending the monthly remittances that her two adult daughters, who live in different parts of Accra, gave her for her own upkeep. Seeing that her daughters were not pleased with her spending the money on the children, Cecilia developed a strategy by offering to do the grocery shopping for her daughters and also cooking for them, to help them with their busy lives. This also allowed her to save a portion of the food to feed the three young children in her care on the days she did the grocery shopping, and to have some surplus for lunch the next day.

Cecilia's case illustrates how caregivers need to manage remittances carefully, especially when these are not enough to cover basic expenses. Often, this material care which they provide from their own resources is not anticipated at the time they agreed to care for a migrant's children, and can become a source of tremendous stress for them. There were also cases of caregivers who needed to borrow money from friends and their adult children. Another caregiver, Takyi, who was taking care of two of his brother-in-law's sons, said the major challenge he faced was delayed remittances when school reopened for the year. After trying several times to raise money to pay the fees himself, he decided to approach the headmasters of the two schools the boys attended to ask for help. He said:

There are times when I do not have anyone to turn to - to borrow money - and that put me under a lot of stress. At some point I decided to go to the headmasters who are aware that the children's parents are abroad, and plead with them to bear with me for some time and that I will pay the fees as soon as I receive the money from the parents or as soon as I am able to raise the money. The headmasters in both schools have been very cooperative in that respect. (Kumasi, November 2011)

Takyi's case is an illustration of how institutions, such as schools with children in transnational families can contribute to reduce the stress on caregivers and by extension on the migrants. Educational institutions which children of migrants attend are affected by such children either because these children may experience particular difficulties related to their parent's migration or due to delayed payment of school fees as in the case above. The schools can help reduce caregivers' burdens by introducing programmes which take care of the needs of the children such as counselling for children who may be having a difficult time dealing with the separation, and also by granting a moratorium in the case of delayed school fees until remittances are received.

Some studies (Åkesson et al., 2012; Pribilsky, 2004) highlight how migrants can be suspicious of caregivers misusing their remittances and as a consequence, children can be taken out of school due to insufficient funds to pay for school fees. In fact, there are programmes being explored by the World Bank to assist migrants in paying school fees directly to schools in order not to have to go through intermediaries (De Archangelis, Joxhe, McKenzie, Tiongson, \& Yang, 2015). Yet in our study, caregivers could negotiate with school authorities when remittances were not forthcoming to pay for 
school fees, by asking schools for a grace period. Their interventions prevented children from having to drop out of school.

The strategies outlined above by caregivers to manage financial resources carefully, especially when remittances are few or not forthcoming, show that along with the visible activities which care entails, caregivers are involved in less visible, but equally important practices that contribute to making care for migrants' children possible.

\section{Discussion and conclusion}

In this paper, we have examined the actual care work performed by caregivers who look after migrants' children in the country of origin. Such care work can be said to constitute a form of social protection, which people in the global South provide for migrants living away. A detailed analysis of what this work entails and the consequences it has for the lives of caregivers has been the focus of study. We argue that a caregiver's resources and services used in providing for migrants' children are part of a reciprocal system of global social protection between migrants and people back home. Migrants are usually portrayed as providers of social protection for their children and other relatives they leave behind or as potential beneficiaries of social protection in the host country. This paper highlights that social protection is actually a reciprocal process involving caregiver resources in terms of time, effort, finances and communication. It is our contention that understanding social protection as a reciprocal process is a fundamental ingredient for thinking about how global social protection can be facilitated to cover both migrants abroad and caregivers back home.

One of our findings points to the fact that although global social protection is a reciprocal process, caregivers struggle to perform their tasks because of the imbalance between what they receive and what is asked of them. Shipton (2007) rightly argues that in the system of entrustment and obligation implied in reciprocal relations, reciprocity can happen over a lifetime, it does not necessarily happen in the same "currency", and it involves both economic and non-economic elements. So, for example, caregivers may derive economic gains as much as gaining satisfaction from projecting an image of doing the socially and culturally "right" thing. This makes a clear evaluation of who benefits more from the arrangement difficult. Nonetheless, we highlight that caregivers often find themselves in a practical bind as they do not receive sufficient remittances to cover the cost of raising the children and providing for housing and expenses to take care of their personal needs, like healthcare which serves as their own social security. This, in some cases, leads to vulnerable situations which require social protection interventions for people linked to migrants and who live in the countries of origin.

We find that caregivers devote a lot of time to caring for migrants' children, at times foregoing their own economic activities in order to have more time for childcare. While extended family ties are important in many countries in the global South, our study of caregivers' care networks - i.e. the people they can count on to receive help to care for a migrant's child - shows that these networks are actually quite restricted. At the same time, caregiving is embedded in a normative context which puts caregivers in a difficult position. They can hardly refuse to take care of a child when requested and, at the same time, they have very little room to complain or change the situation when financial resources are not forthcoming from the migrant. Caregivers were found to contribute their own financial resources when the need arose, but particularly in cases where caregivers had few financial resources this created stress for caregivers. Trust played an important role in facilitating care work. If the migrant trusted the caregiver to be doing his or her best even in difficult circumstances, this helped maintain active and healthy relationships between the caregiver, the migrant parent and the child.

Our study has three implications for thinking about global social protection. Firstly, it is important to recognize the work, in terms of the labour, energy, emotions and resources, experienced by transnational families. Family ties require attention in any context, but when they need to be maintained and care needs to be provided for across great distances they entail a lot of work, financial resources and management of communication which are particular to transnational families. Work conducted 
by people "back home" attests to the fact that migrants not only provide social protection, but they also receive social protection from their families.

Secondly, while our study has focused on childcare, kin work on the part of people in the origin countries is also essential for other domains, such as caring for migrants' elderly parents, constructing houses for migrants, and establishing migrant-owned businesses (Mazzucato, 2011; Van der Geest et al., 2004). All of these activities are related to social protection as these domains provide housing, a source of income, and care for both migrants and the people they are tied to back home. But these domains are not separate from each other. For example, our study has shown that some of the caregivers of migrants' children are themselves the migrants' elderly parents. Both Dankyi (2014) and Mazzucato (2011) show for Ghana as Schmalzbauer (2004) does for Guatemala, that migrants' children can also provide a form of care for their elderly caregivers, such as when children perform services for them, offer companionship, and create the link which keeps migrants actively sending remittances that can, in part, also be used for the care of migrants' elderly parents. Mazzucato (2011) also showed that migrants' housing projects provide housing for their elderly parents, and that business projects help provide a basic income for people back home. The interweaving of domains in which social relationships in one domain may be expressed as a reciprocal "favour" in another domain is an important principle to take into account when thinking of global social protection schemes. If a formalized scheme is designed to replace the informal systems in one domain, it may unwittingly undermine the provision of protection in other domains. The World Bank initiative to provide migrants with the opportunity to pay for their children's school fees in their home countries directly, without going through an intermediary, aimed to remove a possible source of tension from caregivers "misspending" remittances (De Archangelis et al., 2015). Yet it also runs the risk of taking away one of the sources of trust-creation between migrants and caregivers, i.e. the management of remittances. In fact, the World Bank project found that most migrants did not opt for such a system, but rather preferred one that simply "labelled" a remittance as being for education and continued to go through an intermediary. This labelling helps to give migrants more authority in what the remittance should be used for, and caregivers direction that it had to be used for such a purpose, without taking away the opportunities of trust-creation between caregiver and migrant. Such opportunities for "labelling" remittances may serve as a way for both migrants and caregivers to communicate their needs and to account for the actual costs of things in the home countries, about which at times caregivers felt migrants had unrealistic ideas. It may also help foster communication without undermining the trust caregivers and migrants have with each other. Such a "labelling scheme" should help identify caregivers' other needs, for example, a caregiver's own need for elderly care, costs associated with the daily care of children, including the hiring of a helper for the caregiver when needed, and special costs such as the child's health and education. This approach would contribute to recognizing the different components of kin-work.

A third implication of our study is that finances and communication are essential ingredients for building trusting relationships between migrants and caregivers. The caregiving arrangements which worked best - i.e. those with few tensions and in which the child was well taken care of - were those where either the caregiver or the migrant or both had enough financial resources and where they were able to communicate about each other's situation. All of this implies that the migrant parent's condition overseas is intricately related to how well the caregiver is able to care for the migrant's child. If a migrant can send remittances, this eases the situation of the caregiver; if a migrant can communicate easily and frequently, it helps to maintain a healthy relationship with both caregiver and child. It is therefore important, when thinking about how global social protection can be fostered, to consider migrants' situations overseas, especially with respect to the stability of their income and their documented status (Dito, Mazzucato, \& Schans, 2016). These affect what they can do and whether they can travel to see the caregiver and child every once in a while in order to build and maintain a trusting relationship.

Finally, while the role of migrants providing for their families back home has received wide attention, much less attention has gone to the work conducted by people in the home country in order to make transnational families function. Such a transnational perspective implies that social protection requires efforts not only in migrant-destination countries but also in migrant-sending countries. For example, 
in South Africa child support grants are linked to a caregiver irrespective of their biological ties with a child. Such a system recognizes that parents may be absent due to migration or other reasons and that social protection needs to be provided for those who take their place. Recognizing that transnational care is a system of reciprocal relationships built on trust is thus essential when beginning to think of a global social protection system.

\section{Note}

1. Pseudonyms are used throughout to ensure informants' anonymity.

\section{Acknowledgements}

The "Transnational Child Raising Arrangements" (TCRA) research project was directed by Professor Valentina Mazzucato from Maastricht University, and executed in collaboration with Professor Takyiwaa Manuh and Professor Mariama Awumbila from the University of Ghana.

\section{Disclosure statement}

No potential conflict of interest was reported by the authors.

\section{Funding}

This work was supported by Netherlands Organization for Scientific Research, WOTRO Science for Development Division (grant number W01.65.316).

\section{References}

Åkesson, L., Carling, J., \& Drotbohm, H. (2012). Mobility, moralities and motherhood: Navigating the contingencies of Cape Verdean lives. Journal of Ethnic and Migration Studies, 38, 237-260.

Baldassar, L., Baldock, C., \& Wilding, R. (2007). Families caring across borders: Migration, aging and transnational care giving. Canada: Palgrave Macmillan.

Baldassar, L., \& Merla, L. (2014). Introduction: Transnational family caregiving through the lens of circulation. In L. Baldassar \& L. Merla (Eds.), Transnational families, migration and the circulation of care (pp. 3-24). London: Routledge.

Banfi, L., \& Boccagni, P. (2011). Transnational family life and female migration in Italy: One or multiple patterns? In A. Kraler, E. Kofman, M. Kohli, \& C. Schmoll (Eds.), Gender, generations and the family in international migration (pp. 287-313). Amsterdam: Amsterdam University Press.

Bernard, J. K., Landolt, P., \& Goldring, L. (2005). Transnational, multi-local motherhood: Experiences of separation and reunification among Latin American families in Canada (CERIS) (Working Paper No. 40). Toronto: Joint Centre of Excellence for Research on Immigration and Settlement.

Bernardi, L. (2011). A mixed-methods social networks study design for research on transnational families. Journal of Marriage and Family, 73, 788-803.

Bigombe, B., \& Khadiagala G. M. (2003). Major trends affecting families in Sub-Saharan Africa. New York, NY. United Nations. Retrieved June 22, 2012, from http://www.un.org/esa/socdev/family/Publications/mtbigombe.pdf

Bledsoe, C., \& Sow, P. (2011). Back to Africa: Second chances for the children of West African immigrants. Journal of Marriage and Family, 73, 747-762.

Bortei-Doku Aryeety, E., \& Doh, D. (2007). Trends in informal social protection in Ghana. Accra: Ghana Economy Network.

Burt, R. (1984). Network items and the general social survey. Social Networks, 6, 293-339.

Campbell, K. E., \& Lee, B. A. (1991). Name generators in surveys of personal networks. Social Networks, 13, 203-221.

Clark, G. (1999). Mothering, work, and gender in urban Asante ideology and practice. American Anthropologist, 101, $717-729$.

Coe, C. (2011). What is the impact of transnational migration on family life? Women's comparisons of internal and international migration in a small town in Ghana. American Ethnologist, 38, 148-163.

Dankyi, E. (2011). Growing up in a transnational household: A study of children of international migrants in Accra. Ghana Studies, 14, 133-162.

Dankyi, E. (2014). Transnational child raising arrangements: An ethnographic study of transnational caregivers in Ghana (Unpublished Doctoral Thesis). University of Ghana. 
De Archangelis, G., Joxhe, M., McKenzie, D., Tiongson, E., \& Yang, D. (2015). Directing remittances to education with soft and hard commitments: Evidence from a lab-in-the-field experiment and new product take-up among Filipino migrants in Rome (NBER Working Paper No. 20839), Cambridge, MA.

Devereux, S., \& Sabates-Wheeler, R. (2004). Transformative social protection (Working Paper 232). Brighton: IDS

Dito, B., Mazzucato, V., \& Schans, D. (2016). The effects of transnational parenting on the subjective health and wellbeing of Ghanaian migrants in The Netherlands. Population, Space and Place. doi: 10.1002/psp.2006.

Douglass, M. (2006). Global householding in Pacific Asia. International Development Planning Review, 28, 421-446.

Dreby, J. (2010). Divided by borders: Mexican migrants and their children. Berkeley: University of California Press.

Ehrenreich, B., \& Hochschild, A. (Eds.). (2002). Global woman: Nannies, maids and sex workers in the new economy. London: Granta Books.

Fayorsey, C. (1993). Commoditization of childbirth: Female strategies towards autonomy among the Ga of Southern Accra. Cambridge Anthropology, 16, 19-45.

Finch, J., \& Mason, J. (1993). Negotiating family responsibilities. London: Routledge.

Fog Olwig, K. (2014). Migration and care: Intimately related aspects of Caribbean family and kinship. In L. Baldassar \& L. Merla (Eds.), Transnational families, migration and the circulation of care (pp. 133-148). London: Routledge.

Fresnoza-Flot, A. (2009). Migration status and transnational mothering: The case of Filipino migrants in France. Global Networks, 9, 252-270.

Fresnoza-Flot, A. (2014). Men's caregiving practices in Filipino transnational families: A case study of left-behind fathers and sons. In L. Baldassar \& L. Merla (Eds.), Transnational families, migration and the circulation of care (pp. 170-184). London: Routledge.

Goody, E. (1982). Parenthood and social reproduction: Fostering and occupational roles in West Africa. Cambridge: Cambridge University Press.

Graham, E., \& Jordan, L. (2011). Migrant parents and the psychological well-being of left-behind children in Southeast Asia. Journal of Marriage and Family, 73, 763-787.

Haagsman, K., Mazzucato, V., \& Dito, B. (2015). Transnational families and the subjective well-being of migrant parents: Angolan and Nigerian parents in The Netherlands. Ethnic and Racial Studies,38, 2652-2671.

Hondagneu-Sotelo, P., \& Avila, E. (1997). "I'm here, but I'm there": The meanings of Latina Transnational motherhood. Gender and Society, 11, 548-571.

Horst, H. (2006). The blessings and burdens of communication: Cell phones in Jamaican transnational social fields. Global Networks, 6, 143-159.

House, J. S. (1981). Work stress and social support. Reading, MA: Addison- Wesley.

Israel, B. A. (1982). Social networks and health status: Linking theory, research, and practice. Patient Counselling Health Education, 4, 65-79.

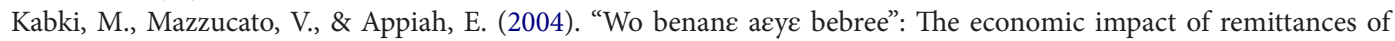
Netherlands-based Ghanaian migrants on rural Ashanti. Population, Space and Place, 10, 85-97.

Madiannou, M., \& Miller, D. (2012). Migration and new media: Transnational families and polymedia. London: Routledge.

Mazzucato, V. (2009). Bridging boundaries with a transnational research approach: A simultaneous matched sample methodology. In M. A. Falzon (Ed.), Multi-sited ethnography: Theory, praxis and locality in contemporary social research (pp. 215-232). Hampshire: Ashgate.

Mazzucato, V. (2011). Reverse remittances in the migration development-nexus: Two way flows between Ghana and The Netherlands. Population, Space and Place, 17, 454-468.

Mazzucato, V., Cebotari, V., Veale, A., White,A., Grassi, M., \& Vivet, J. (2015). International parental migration and the psychological well-being of children in Ghana, Nigeria, and Angola. Social Science and Medicine, 132, $215-224$. doi:10.1016/j.socscimed.2014.10.058

Mazzucato, V., \& Schans, D. (2011). Transnational families and the well-being of children: Conceptual and methodological challenges. Journal of Marriage and Family, 73, 704-712.

Mazzucato, V., van den Boom, B., \& Nsowah-Nuamah, N. N. N. (2008). Remittances in Ghana: Origin, destination and issues of measurement. International Migration, 46, 103-122.

Moran-Taylor, M. J. (2008). When mothers and fathers migrate North: Caretakers, children, and child rearing in Guatemala. Latin American Perspectives, 35, 79-95.

Nobles, J. (2011). Parenting from abroad: Migration, nonresident father involvement, and children's education in Mexico. Journal of Marriage and Family, 73, 729-746.

Nukunya, G. K. (2003). Tradition and change in Ghana: An introduction to sociology. Accra: Ghana Universities Press.

Øien, C. (2006). Transnational networks of care: Angolan children in fosterage in Portugal. Ethnic and Racial Studies, 29, 1104-1117.

Oppong, C. (1982). Family structure and women's reproductive and productive roles. In R. Anker, M. Buvinic, \& N. Youssef (Eds.), Women's roles and population trends in the Third World (pp. 133-150). London: Croom Helm.

Parreñas, R. S. (2001). Servants of globalization: Women, migration and domestic work. Stanford, CA: Stanford University Press.

Parreñas, R. S. (2005). Children of global migration: Transnational families and gendered woes. Stanford, CA: Stanford University Press. 
Poeze, M., \& Dankyi, E. (2013). Eén familie, twee landen, twee onderzoeksters: Ervaringen met een simultaneous matched sample methodology [One family, two countries, two researchers: Experiences with a simultaneous matched sample methodology]. Kwalon, 18, 41-46.

Poeze, M., \& Mazzucato, V. (2012, December 6-7). Transnational fathering between the Netherlands and Ghana: Fathers' perceptions, obstacles and opportunities. Paper presented at the conference Rethinking Care: Anthropological Perspectives on Life Courses, Kin-Work and their trans-local entanglements, Berlin.

Poeze, M., \& Mazzucato, V. (2014). Ghanaian children in transnational families: Understanding the experiences of leftbehind children through local parenting norms. In L. Baldassar \& L. Merla (Eds.), Transnational families, migration and the circulation of care (pp. 149-169). London: Routledge.

Pribilsky, J. (2004). 'Aprendemos a convivir': Conjugal relations, co-parenting, and family life among Ecuadorian transnational migrants in New York and the Ecuadorian Andes. Global Networks, 4, 313-334.

Sabates-Wheeler, R., \& Waite, M. (2003). Migration and social protection: A concept paper. Development Research Centre on Migration, Globalization and Poverty, Working Paper T2, International Development Studies, Sussex University, Sussex.

Schmalzbauer, L. (2004). Searching for wages and mothering from Afar: The case of Honduran transnational families. Journal of Marriage and Family, 66, 1317-1331.

Shipton, P. (2007). The nature of entrustment: Intimacy, exchange, and the sacred in Africa. New Haven, CT: Yale University.

UNICEF. (2006). Promoting the rights of children affected by migration: UNICEF Report following the HLD on International Migration and Development. New York, NY: UNICEF.

UNICEF. (2009). Social protection and children: Opportunities and challenges in Ghana. New York, NY: UNICEF.

Van der Geest, S., Mul, A., \& Vermeulen, H. (2004). Linkages between migration and the care of frail older people: Observations from Greece, Ghana and The Netherlands. Ageing and Society, 24, 431-450.

Vanore, M., Mazzucato, V., \& Siegel, M. (2015). "Left behind” but not left alone: Parental migration \& the psychosocial health of children in Moldova. Social Science and Medicine, 132, 252-260. doi:10.1016/j.socscimed.2014.08.040

Wetherell, C. (1998). Historical social network analysis. International Review of Social History, 43, 125-144.

Wong, M. (2006). The gendered politics of remittances in Ghanaian transnational families. Economic Geography, 82, 355-381.

Wu, Q., Lu, D., \& Kang, M. (2015). Social capital and the mental health of children in rural China with different experiences of parental migration. Social Science \& Medicine, 132, 270-277. doi:10.1016/j.socscimed.2014.08.050 